\title{
PENGARUH PENGGUNAAN KURSI PERSALINAN BC-MK15 TERHADAP KETIDAKNYAMANAN BIDAN DALAM PERTOLONGAN PERSALINAN
}

\section{EFFECT OF THE USE OF THE BC-MK15 BIRTH CHAIR TO THE MIDWIFE DISCOMFORT LEVEL DURING DELIVERY CARE}

\author{
Hani Sutianingsih, ${ }^{1}$ Johanes C. Mose, ${ }^{2}$ Farid Husin, ${ }^{3}$ \\ ${ }^{1}$ Poltekkes Kemenkes Banten \\ ${ }^{2}$ Departemen Obstetri dan Ginekologi Fakultas Kedokteran Universitas Padjadjaran \\ ${ }^{3}$ Departemen Epidemiologi dan Biostatistika Fakultas Kedokteran Univeritas \\ padjadjaran \\ Korespondensi: hanisutianingsih@gmail.com
}

\begin{abstract}
Midwife has risks in their work, such as at first stage delivery care, they have risk of unnatural work posture, while in the second and third stage midwife experiences a body irregularity which can be seen in the spinal segment and postural instability. Unusual work postures continuously can cause musculoskeletal disorders (MSD). The etiology of musculoskeletal disorders is very complicated and controversial, so the lack of information can lead to more difficult risk management, but by detecting discomfort is very useful as an indicator of the risk of musculoskeletal disorders, thus minimizing the discomfort may contribute to reducing risk of musculoskeletal disorders, since both are known associated with exposure to the musculoskeletal system by biomechanical loads. The importance of the ergonomics aspect for the midwife to reduce the discomfort of the body in doing it's work, is strongly supported by the appropriate facilities such as the $B C-M K 15$ birth chair. This research is quasi experimental with simple random sampling, subject is divided into two groups, intervention and control (22 midwives each group) who work at Puskesmas Garuda, Puter and Ibrahim Adji Bandung. Discomfort scoring using Body Part Discomfort Scale (BPDS). Statistical test using Kolmogorov -Smirnov analysis to see the difference of discomfort between treatment and control group for each stage of delivery care, and Chi-Square test to see the effect between the two study groups also Mann-Whitney test to see the discomfort diffrences between each group for the whole stage of delivery care (stage I-III). The significance level been decided for $p<0.05$. The results showed that there was an effect of the use of the BC-MK15 birth chair to the midwife discomfort level for each body part in every stage during delivery care, and there was a lower median rate of discomfort in the intervention group compare to the control group The conclusion was the use of BCMK15 birth chairs can decrease midwife discomfort for every stage during delivery care in the intervention group compare to the control group.
\end{abstract}

Keywords: BC-MK15 Birth Chair, Discomfort, Midwife 


\section{ABSTRAK}

Bidan mengalami risiko pekerjaan saat menolong persalinan kala I salah satunya adalah adanya postur kerja yang tidak alamiah, sementara pada kala II dan kala III bidan mengalami ketidakselaran tubuh yang dapat dilihat pada segmen tulang belakang serta adanya ketidakstabilan postur. Postur kerja tidak alamiah bila dilakukan secara terus menerus dapat menyebabkan gangguan muskuloskeletal. Etiologi gangguan muskuloskeletal sangat rumit dan kontroversial, namun dengan mendeteksi adanya ketidaknyamanan sangat berguna sebagai indikator risiko gangguan muskuloskeletal, sehingga dengan meminimalisir ketidaknyamanan dapat berkontribusi pada penurunan risiko gangguan muskuloskeletal, karena keduanya diketahui berhubungan dengan keterpaparan pada sistem muskuloskeletal oleh beban biomekanik. Pentingnya aspek ergonomi bagi bidan untuk mengurangi ketidaknyamanan tubuh dalam melakukan pekerjaannya sangat didukung oleh adanya sarana yang sesuai seperti kursi persalinan BC-MK15. Penelitian ini bersifat quasi eksperimental dengan jumlah sampel 44 bidan di Puskesmas Garuda, Puter dan Ibrahim Adji Kota Bandung dengan teknik pengambilan sampel simple random sampling dibagi dua kelompok, kelompok perlakuan dan kelompok kontrol masing-masing berjumlah 22 orang. Penilaian skor ketidaknyamanan menggunakan Body Part Discomfort Scale (BPDS). Pengujian statistik untuk melihat perbedaan tingkat ketidaknyamanan antara kelompok perlakuan dengan kontrol menggunakan uji Kolmogorov-Smirnov, sementara untuk melihat pengaruh penggunaan kursi persalinan pada setiap kala persalinan menggunakan nilai RR pada uji Chi-Kuadrat dan untuk melihat tingkat ketidaknyamanan selama pertolongan kala I sampai III diuji dengan uji Mann-Whitney. Nilai kemaknaan ditentukan sebesar $\mathrm{p}<0,05$. Hasil penelitian menunjukan penggunaan kursi persalinan berpengaruh terhadap ketidaknyamanan anggota tubuh kala I, II dan III, sementara untuk ketidaknyamanan bidan selama pertolongan persalinan mulai kala I sampai III menunjukan nilai yang lebih rendah pada kelompok perlakuan dibanding kontrol. Simpulan penelitian ini adalah penggunaan kursi persalinan BC-MK15 dapat menurunkan ketidaknyamanan bidan saat melakukan pertolongan kala I, II dan III persalinan.

\section{Kata kunci: Bidan , Faktor Individu, MSD, pertolongan persalinan}

\section{PENDAHULUAN}

Risiko pada bidan saat melakukan pertolongan persalinan adalah postur janggal yang membuat bidan harus membungkuk kedepan, miring dan memutar, seperti pada saat melakukan pemeriksaan pervaginam pada kala I persalinan, sementara pada kala II dan III persalinan, penelitian di Polandia menyebutkan bahwa bidan mengalami ketidakselarasan pada segmen tulang belakang serta adanya ketidakstabilan postur. Postur kerja yang janggal bila dilakukan secara terus menerus dapat 
menyebabkan ketidaknyamanan dan gangguan muskuloskeletal (musculosceletal disorders/MSD).

Sebuah studi di Australia menyebutkan mengenai gangguan muskuloskeletal yang dirasakan bidan saat bekerja sebanyak 48,8\% pada leher, 61,2\% punggung bawah dan $29,2 \%$ pada punggung atas. ${ }^{3,4,5,6} \mathrm{Di}$ Indonesia penelitian mengenai hubungan antara karakteristik posisi kerja bidan dengan nyeri punggung bawah banyak diakibatkan dari posisi berdiri yang lebih lama $\quad(86,67 \%)$ dan kondisi membungkuk $20^{\circ}-60^{\circ}(70,83 \%)$. Salah satu penelitian mengenai keluhan gangguan otot pada bidan di Indonesia menyebutkan bahwa nilai terbesar risiko bidan saat melakukan pertolongan persalinan terjadi pada tubuh bagian atas (upper quadrant MSDs) seperti pada leher (neck), lengan atas (upper arm), pergelangan tangan (wrist) dan punggung atas (trunk).

\section{Etiologi}

gangguan

muskuloskeletal yang sering terjadi pada pekerja sangat rumit dan kontroversial, sehingga kurangnya informasi mengenai hal ini dapat menyebabkan pengelolaan risiko menjadi lebih sulit. Namun dengan mendeteksi adanya ketidaknyamanan sangat berguna sebagai indikator risiko gangguan muskuloskeletal,. ${ }^{10,11}$ Adanya penurunan ketidaknyamanan dapat berkontribusi pada penurunan risiko gangguan muskuloskeletal, karena keduanya diketahui berhubungan dengan keterpaparan pada sistem muskuloskeletal oleh beban biomekanik. ${ }^{10,11,12}$

Di Indonesia, postur janggal/sikap kerja tidak alamiah yang menyebabkan ketidaknyamanan muskuloskeletal lebih banyak diakibatkan oleh adanya ketidaksesuaian antara dimensi alat dan stasiun kerja dengan ukuran tubuh pekerja, sehingga penerapan ergonomi pada lingkungan kerja bidan menjadi salah satu upaya untuk mengurangi permasalahan dalam sikap kerja bidan, karena prinsip ergonomi yang berpusat pada pendekatan manusia dalam perancangan kerja, peralatan kerja, sistem kerja dan sebagainya, agar sesuai dengan individu manusia. Salah satu area dalam risiko kerja bidan adalah posisi saat melakukan pertolongan persalinan yang berkaitan dengan sarana dalam proses persalinan seperti tempat tidur bersalin. Penelitian sebelumnya mengenai analisis keluhan fisik bidan akibat menolong persalinan di Kab. Serang, menunjukan bahwa 
ketinggian tempat tidur bersalin yang tidak sesuai dengan tinggi badan bidan menyebabkan keluhan muskuloskeletal pada bidan, sehingga menyebabkan sikap kerja yang tidak ergonomis (membungkuk dan menoleh kearah jalan lahir secara bersamaan) yang dilakukan berulang-ulang (repetitif) dalam rentang waktu yang lama. Penelitian ini menyarankan adanya penelitian selanjutnya mengenai interaksi bidan dan tempat tidur bersalin selama menolong persalinan dan rancangan stasiun kerja tempat tidur bersalin harus lebih ergonomis dan sesuai dengan konteks kultur budaya daerah di Indonesia. Pentingnya aspek ergonomi bagi bidan untuk mengurangi ketidaknyamanan tubuh dalam melakukan pekerjaannya sangat didukung oleh adanya sarana yang sesuai dengan anthropometri bidan. Hal ini memotivasi adanya sebuah inovasi dalam sarana pendukung proses persalinan, salah satunya adalah kursi persalinan. ${ }^{2,13,14,15}$

Salah satu kursi persalinan yang diharapkan dapat memfasilitasi bidan untuk meraih kenyamanan dalam bekerja, adalah kursi persalinan BC-MK 15 (Birth Chair Magister Kebidanan 15) yang dirancang memiliki ketinggian yang dapat disesuaikan dengan postur kerja berdiri dan sesuai dengan antropometri bidan. Selain itu pada bagian penyangga panggul, kursi persalinan memiliki void (lekukan) daerah bawah lumbar untuk mempermudah akses saat kepala dan tubuh bayi lahir, sehingga dapat mempermudah bidan saat melahirkan bayi pada saat kala II persalinan dan menjaga keamanan bayi saat keluar dari jalan lahir. Penyangga tubuh bagian bawah dan penyangga kaki pada kursi persalinan BC-MK15 dapat dilepas dan dipindahkan sehingga mempermudah bidan saat melahirkan badan bayi dan pada saat melakukan penjahitan laserasi perineum ataupun tindakan pervaginam lain yang memerlukan akses lapang pandang yang luas dari jalan lahir, sesuai dengan harapan bidan yang menginginkan adanya kemudahan pada saat melahirkan kepala dan tubuh bayi pada kala II persalinan. ${ }^{9,16}$

Tingginya risiko ketidaknyamanan akibat ketidaksesuaian antara bidan dengan sarana pertolongan persalinan menjadi dasar perlunya sebuah analisa terhadap pengaruh sarana pertolongan persalinan dalam menurunkan ketidaknyamanan bidan selama bekerja. Sebuah studi ergonomi menyebutkan 
bahwa efek jangka pendek sebuah intervensi ergonomi, dapat dilihat dari hasil pengukuran ketidaknyamanan yang dirasakan pekerja saat bekerja, sehingga dengan mengukur ketidaknyamanan yang dirasakan bidan saat melakukan pertolongan persalinan dapat mendeteksi efek jangka pendek (pengaruh) dari penggunaan kursi persalinan sebagai intervensi ergonomis. ${ }^{17}$ Pada akhirnya, desain kursi persalinan yang ergonomis diharapkan dapat menguntungkan bagi bidan, sehingga kursi persalinan dapat menjawab kebutuhan bidan akan sarana yang dapat meminimalisir ketidaknyamanan selama melakukan pertolongan persalinan.

\section{METODE}

Penelitian ini merupakan studi quasi eksperimental dengan desain Post test with control group design yang dilakukan pada bidan yang melakukan pertolongan persalinan di Puskesmas dengan Pelayanan Obstetri dan Neonatal Emergensi Dasar (PONED) Kota Bandung yang memenuhi kriteria inklusi. Puskesmas PONED tersebut diantaranya adalah Puskesmas Puter, Garuda, dan Ibrahim Adjie. Pengambilan sampel adalah dengan simple random sampling pada bulan April-Mei tahun 2017. Kriteria inklusi pada penelitian ini yaitu bidan lulusan D III Kebidanan, menangani pasien kala I sampai kala III, masih aktif melakukan pertolongan persalinan dalam satu bulan terakhir Adapun kriteria eksklusi pada penelitian ini adalah bidan yang sedang memiliki keluhan pada fisik, seperti Influenza, hipertensi dan gangguan muskuloskeletal pada saat pengambilan data. Karakteristik bidan yang berpengaruh terhadap ketidaknyamanan saat pertolongan persalinan seperti usia, masa kerja, tinggi badan, indeks masa tubuh dan lama persalinan ikut serta dianalisis dalam penelitian ini untuk melihat keberadaan pengaruh karakteristik sebagai variabel perancu. Pengukuran ketidaknyamanan setiap anggota tubuh pada setiap kala persalinan diukur dengan menggunakan kuesioner Body Part Discomfort Scale, sementara untuk pengukuran ketidaknyamanan bidan selama pertolongan persalinan dari kala I sampai kala III dilakukan dengan melihat perbandingan antara angka median pada kelompok perlakuan dengan kelompok kontrol. Pengisian kuesioner dilakukan pada akhir persalinan (setelah selesai kala IV persalinan) 


\section{HASIL DAN PEMBAHASAN}

Responden pada penelitian ini adalah bidan berjumlah 44 orang yang bekerja di Puskesmas PONED Garuda, Ibrahim Adjie dan Puter Kota Bandung. Karakteristik subjek pada penelitian ini dapat dilihat pada tabel 1:

Tabel 1. Karakteristik Subjek Penelitian

\begin{tabular}{|c|c|c|c|}
\hline \multirow{2}{*}{$\begin{array}{l}\text { Karakteristik } \\
\text { Responden }\end{array}$} & \multicolumn{2}{|c|}{ Kelompok } & \multirow[t]{2}{*}{ Nilai $\mathrm{p}$} \\
\hline & $\begin{array}{c}\text { Perlakuan } \\
(n=22)\end{array}$ & $\begin{array}{c}\text { Kontrol } \\
(\mathrm{n}=22)\end{array}$ & \\
\hline \multicolumn{4}{|l|}{ Usia (tahun) } \\
\hline$<35$ & 11 & 14 & $0,361 *$ \\
\hline$\geq 35$ & 11 & 8 & \\
\hline Masa Kerja (tahun) & & & $0,240 *$ \\
\hline$\leq 5$ & 6 & 2 & \\
\hline$>5$ & 16 & 20 & \\
\hline \multicolumn{4}{|l|}{ Tinggi Badan (cm) } \\
\hline $150-158$ & 13 & 13 & $1,000^{*}$ \\
\hline$\geq 159$ & 9 & 9 & \\
\hline \multicolumn{4}{|l|}{ IMT } \\
\hline Kurus & 0 & 1 & \\
\hline Normal & 22 & 20 & $1,000 * *$ \\
\hline Gemuk & 0 & 1 & \\
\hline $\begin{array}{ll}\text { Lama } & \text { Persalinan } \\
\text { (menit) } & \end{array}$ & $242,14(17,649)$ & $263,02(32,648)$ & $0,054 * *$ \\
\hline Kala I (mean,SD) & $19,83(4,562)$ & $27,28(5,015)$ & $0,000 * * *$ \\
\hline Kala II (mean,SD) & $6,02 \quad(0,922)$ & $7,46(2,638)$ & $0,054 * *$ \\
\hline Kala III (mean,SD) & & & \\
\hline
\end{tabular}

Tabel 1 menunjukkan bahwa hanya kategori lama persalinan kala II yang memiliki nilai kemaknaan $\mathrm{p}<0,05$

Tabel 2. Pengaruh penggunaan kursi kersalinan BC-MK15 terhadap ketidaknyamanan anggota tubuh antara kelompok perlakuan dengan kelompok kontrol padapertolongan persalinan kala I

\begin{tabular}{|c|c|c|c|c|c|c|}
\hline \multirow{2}{*}{\multicolumn{2}{|c|}{ Ketidaknyamanan }} & \multicolumn{2}{|c|}{ Kelompok } & \multirow[b]{2}{*}{ Nilai p* } & \multirow[b]{2}{*}{$\mathbf{R R}$} & \multirow{2}{*}{$\begin{array}{l}95 \% \text { Interval } \\
\text { kepercayaan }\end{array}$} \\
\hline & & $\begin{array}{l}\text { Kontrol } \\
(n=22)\end{array}$ & $\begin{array}{c}\text { Perlakuan } \\
(\mathrm{n}=22)\end{array}$ & & & \\
\hline \multicolumn{7}{|l|}{ Leher dan Bahu } \\
\hline Tidak nyaman & & 2 & 1 & $1,000^{*}$ & 2,000 & $0,195-20,486$ \\
\hline Nyaman & & 20 & 21 & & & \\
\hline $\begin{array}{l}\text { Lengan dan } \\
\text { tangan }\end{array}$ & Pergelangan & & & & & \\
\hline Tidak nyaman & & 5 & 1 & $0,185^{*}$ & 5,000 & $0,635-39,391$ \\
\hline Nyaman & & 17 & 21 & & & \\
\hline \multicolumn{7}{|l|}{ Punggung atas } \\
\hline Tidak nyaman & & 10 & 2 & $0,007 *$ & 5,000 & $1,235-20,245$ \\
\hline Nyaman & & 12 & 20 & & & \\
\hline \multicolumn{7}{|c|}{ Punggung bawah } \\
\hline Tidak nyaman & & 12 & 2 & $0,001 *$ & 6,000 & $1,516-23,739$ \\
\hline Nyaman & & 10 & 20 & & & \\
\hline
\end{tabular}

Keterangan : p*chi kuadrat 
Tabel 2 memperlihatkan bahwa pada anggota tubuh leher bahu serta lengan dan pergelangan tangan tidak menunjukan adanya pengaruh yang signifikan berdasarkan uji chi kuadrat, kecuali pada bagian punggung atas dan punggung bawah yang memiliki nilai probabilitas kurang dari $0,05(\mathrm{p}<0,05)$.

Tabel 3 Pengaruh penggunaan kursi kersalinan BC-MK15 terhadap ketidaknyamanan anggota tubuh antara kelompok perlakuan dengan kelompok kontrol padapertolongan persalinan kala II

\begin{tabular}{|c|c|c|c|c|c|}
\hline \multirow[b]{2}{*}{ Ketidaknyamanan } & \multicolumn{2}{|c|}{ Kelompok } & \multirow[b]{2}{*}{ Nilai $\mathbf{p}^{*}$} & \multirow[b]{2}{*}{$\mathbf{R R}$} & \multirow{2}{*}{$\begin{array}{l}\text { 95\% Interval } \\
\text { kepercayaan }\end{array}$} \\
\hline & $\begin{array}{l}\text { Kontrol } \\
(\mathrm{n}=22)\end{array}$ & $\begin{array}{c}\text { Perlakuan } \\
(\mathrm{n}=22)\end{array}$ & & & \\
\hline $\begin{array}{l}\text { Leher dan Bahu } \\
\text { Tidak nyaman } \\
\text { Nyaman }\end{array}$ & $\begin{array}{l}9 \\
13\end{array}$ & $\begin{array}{l}1 \\
21\end{array}$ & $0,004 *$ & 9,000 & $1,243-65,163$ \\
\hline $\begin{array}{l}\text { Lengan dan Pergelangan } \\
\text { tangan }\end{array}$ & & & & & \\
\hline $\begin{array}{l}\text { Tidak nyaman } \\
\text { Nyaman }\end{array}$ & $\begin{array}{l}15 \\
7\end{array}$ & $\begin{array}{l}2 \\
20\end{array}$ & $0,000^{*}$ & 7,500 & $1,941-28,985$ \\
\hline $\begin{array}{l}\text { Punggung atas } \\
\text { Tidak nyaman } \\
\text { Nyaman }\end{array}$ & $\begin{array}{l}11 \\
11\end{array}$ & $\begin{array}{l}1 \\
21\end{array}$ & $0,001 *$ & 11,000 & $1,549-78,090$ \\
\hline $\begin{array}{l}\text { Punggung bawah } \\
\text { Tidak nyaman } \\
\text { Nyaman }\end{array}$ & $\begin{array}{l}17 \\
5\end{array}$ & $\begin{array}{l}2 \\
20\end{array}$ & $0,000^{*}$ & 8,500 & $2,224-32,485$ \\
\hline $\begin{array}{l}\text { Kaki } \\
\text { Tidak nyaman } \\
\text { Nyaman }\end{array}$ & $\begin{array}{l}14 \\
8\end{array}$ & $\begin{array}{l}2 \\
20\end{array}$ & $0,000^{*}$ & 7,000 & $1,799-27,236$ \\
\hline
\end{tabular}

Keterangan : $\mathrm{p}^{*}$ chi kuadrat

Tabel 3. Menunjukan bahwa penggunaan kursi persalinan BC-MK15 saat pertolongan persalinan kala II berpengaruh pada seluruh anggota tubuh $(\mathrm{p}<0,05)$ yang berarti tingkat ketidaknyamanan anggota tubuh pada kelompok perlakuan lebih rendah dari kelompok kontrol

Tabel 4. Pengaruh penggunaan kursi kersalinan BC-MK15 terhadap ketidaknyamanan anggota tubuh antara kelompok perlakuan dengankelompok kontrol padapertolongan persalinan kala III

\begin{tabular}{|c|c|c|c|c|c|}
\hline \multirow[b]{2}{*}{ Ketidaknyamanan } & \multicolumn{2}{|c|}{ Kelompok } & \multirow[b]{2}{*}{ Nilai $\mathbf{p}^{*}$} & \multirow[b]{2}{*}{$\mathbf{R R}$} & \multirow{2}{*}{$\begin{array}{l}\text { 95\% Interval } \\
\text { kepercayaan }\end{array}$} \\
\hline & $\begin{array}{l}\text { Kontrol } \\
(\mathrm{n}=22)\end{array}$ & $\begin{array}{c}\begin{array}{c}\text { Perlakuan } \\
(\mathrm{n}=22)\end{array} \\
\end{array}$ & & & \\
\hline \multicolumn{6}{|l|}{ Leher dan Bahu } \\
\hline Tidak nyaman & 8 & 2 & $0,031 *$ & 4,000 & $0,955-16,754$ \\
\hline Nyaman & 14 & 20 & & & \\
\hline
\end{tabular}




\begin{tabular}{llllll}
\hline $\begin{array}{l}\text { tangan } \\
\text { Tidak nyaman } \\
\text { Nyaman }\end{array}$ & 15 & 5 & $0,002^{*}$ & 3,000 & $1,319-6,823$ \\
$\begin{array}{l}\text { Punggung atas } \\
\text { Tidak nyaman } \\
\text { Nyaman }\end{array}$ & 7 & 17 & & & \\
$\begin{array}{l}\text { Punggung bawah } \\
\text { Tidak nyaman }\end{array}$ & 14 & 3 & $0,001^{*}$ & 4,667 & $1,556-13,992$ \\
$\begin{array}{l}\text { Nyaman } \\
\text { Kaki }\end{array}$ & 8 & 19 & & & \\
$\begin{array}{l}\text { Tidak nyaman } \\
\text { Nyaman }\end{array}$ & 4 & 2 & $0,000^{*}$ & 9,000 & $2,366-34,234$ \\
\hline & 18 & 20 & & & \\
\hline
\end{tabular}

Keterangan : $\mathrm{p}^{*}$ chi kuadrat

Tabel 4. Menunjukan bahwa penggunaan kursi persalinan BC-MK15 saat pertolongan persalinan kala III berpengaruh pada seluruh anggota tubuh $(\mathrm{p}<0,05)$ yang berarti tingkat ketidaknyamanan anggota tubuh pada kelompok perlakuan lebih rendah dari kelompok kontrol.

Tabel 5. Pengaruh penggunaan kursi kersalinan BC-MK15 terhadap ketidaknyamanan bidan antara kelompok perlakuan dengan kelompok kontrol selamapertolongan persalinan kala I sampai kala III.

\begin{tabular}{lll} 
Ketidaknyamanan & Median, Rentang & $\mathbf{p}^{*}$ \\
\hline Perlakuan (n=22) & $30(7-82)$ & 0,000 \\
Kontrol (n=22) & $63,5(22-96)$ & \\
\hline P*Mann Whitney & &
\end{tabular}

Tabel 5. Menunjukan bahwa dari pengkategorian nyaman dan tidak nyaman, skor total untuk kategori nyaman adalah 56 (16 skor total untuk anggota tubuh kala I, 20 untuk skor total anggota tubuh kala II, dan 20 untuk skor total kala III), sementara untuk kategori tidak nyaman memiliki skor diatas 56. Median pada kelompok perlakuan berada pada nilai 30, sehingga dapat disimpulkan bahwa subjek penelitian yang menggunakan kursi persalinan BC-MK15 berada pada kategori nyaman, sementara subjek penelitian pada kelompok kontrol berada pada kategori tidak nyaman dengan nilai median 63,5 . 
Karakteristik kerja bidan pada kala I persalinan, bidan akan melakukan observasi kemajuan persalinan dan pemeriksan tanda-tanda vital seperti pemeriksaan tekanan darah, pernafasan, nadi dan respirasi serta pemeriksaan his, denyut jantung janin dan pemeriksaan pervaginam (vaginal tusee). Menurut salah satu penelitian, bidan banyak memiliki risiko untuk memutar pinggang dan melengkungkan tulang belakang pada saat melakukan pemeriksaan tekanan darah dan denyut jantung janin serta pada saat memfasilitasi kebutuhan dasar manusia seperti mengganti baju pasien, mengantar ke kamar mandi, dsb. ${ }^{3}$ Apabila dilakukan secara terus menerus (repetitif) hal ini akan menyebabkan gangguan otot pada daerah kuadran atas /punggung atas (work related upper quadran musculosceletal disorders), seperti yang diungkapkan Long dalam ulasan sistematisnya bahwa postur janggal/sikap kerja tidak alamiah akan berisiko menyebabkan gangguan muskuloskeletal sebanyak 2 kali pada daerah leher, bahu dan punggung atas. 28 Fitur pengaturan ketinggian pada kursi persalinan BC-MK15 membantu bidan pada saat melakukan pemantauan kala I persalinan, terutama pada saat melakukan pemeriksaan per vaginam untuk mengetahui kemajuan persalinan. Dengan fitur pengaturan ketinggian yang dapat disesuaikan dengan tinggi badan bidan, maka punggung atas dan bawah tidak akan terlalu membungkuk pada saat pemeriksaan pervaginam, meskipun lengan dan pergelangan tangan tetap memutar dan melekuk karena harus menyesuaikan dengan jalan lahir. Hal inilah yang menyebabkan penggunaan kursi persalinan BC-MK15 memiliki pengaruh terhadap penurunan ketidaknyamanan daerah punggung atas dan bawah selama pertolongan kala I persalinan, yang disebabkan oleh penggunaan fitur pengaturan ketinggian kursi persalinan BC-MK15 yang meminimalisir risiko postur kerja tidak alamiah saat kala I persalinan.

Saat pertolongan persalinan kala II, pada kelompok kontrol yang menolong persalinan disamping tempat tidurakan membuat leher, bahu, punggung atas dan bawah memutar dan menunduk untuk menyesuaikan dengan ketinggian dan posisi tempat tidur bersalin, bahkan pada penelitian di Polandia menunjukan bahwa terdapat signifikansi pada hiperekstensi leher, sedikit hiperekstensi pada tulang 
belakang bagian thoracic dan fleksi pada daerah lumbar saat bidan melakukan pertolongan persalinan. ${ }^{4}$ Tanpa disadari, bidan telah melakukan sikap kerja yang janggal. Meskipun sesekali bidan meluruskan tubuhnya untuk relaksasi, bidan telah mengalami postur statis dalam waktu yang lama. Secara umum postur statis dapat terjadi pada sikap tubuh yang membutuhkan tenaga sedang selama 1 (satu) menit atau lebih, seperti yang terjadi pada pertolongan persalinan kala II. Pada kala II bidan akan cenderung berada pada dalam postur statis yang akan meningkatkan jumlah tenaga yang dibutuhkan karena kekuatan kontraksi haus dipertahankan untuk menahan tubuh dalam posisi yang sama. Posisi leher, bahu dan punggung pada pertolongan persalinan kala II berada pada posisi yang tidak alamiah bila terjadi dalam waktu yang lama dapat menyebabkan adanya ketidaknyamanan yang dirasakan bidan, sesuai dengan Tarwaka yang menyebutkan bahwa sikap kerja tidak alamiah dapat menyebabkan bagian-bagian tubuh bergerak menjauhi posisi alamiah, maka semakin jauh posisi bagian tubuh dari pusat gravitasi tubuh, akan semakin tinggi risiko terjadinya keluhan otot skeletal yang bermula dari iskemia yang dapat meningkatkan kadar $\mathrm{CO}_{2}$ dan zat limbah lain, seperti asam laktat. 4,8,13,26

Pada kelompok perlakuan yang menggunakan kursi persalinan BCMK15 bidan akan memanfaatkan fitur penyesuaian ketinggian, fitur void (lekukan daerah panggul pasien) dan fitur bagian bawah kursi yang dapat dicopot, bidan akan mendapatkan ketinggian kursi yang sesuai dengan tinggi badannya dan berada tepat didepan jalan lahir, sehingga tubuh bidan akan cenderung dalam posisi netral. Hal inilah yang membuat gejala ketidaknyamanan semakin berkurang pada kelompok perlakuan, sesuai dengan penelitian mengenai efek meja kerja elektronik yang dapat diatur ketinggiannya terhadap ketidaknyamanan pekerja yang memberikan efek penurunan ketidaknyamanan pada daerah leher, bahu, punggung atas dan punggung bawah. ${ }^{40}$ Selain itu penggunaan kursi persalinan BC-MK15 pun dapat mengurangi risiko ketidaknyamanan dibagian leher dan bahu sebesar 89\%, punggung atas sebesar $90 \%$ dan bagian punggung bawah sebesar $88 \%$.

Karakteristik kerja bidan di kala III hampir sama dengan kala II 
persalinan. Pada kala III persalinan subjek penelitian di kelompok kontrol melakukan pertolongan persalinan dengan posisi berdiri dari samping tempat tidur untuk dapat menyesuaikan dengan posisi ibu bersalin. Kegiatan ini dilakukan antara 5 hingga 30 menit, kegiatan ini termasuk kedalam postur statis menurut Kroemer dan Gradjen postur statis adalah postur yang membutuhkan tenaga ringan (sekitar sepertiga dari jumlah tenaga maksimum tubuh) selama 5 menit atau lebih. ${ }^{48}$

Hasil analisis postur pada penelitian Komala menunjukan bahwa pertolongan kelahiran plasenta memiliki nilai risiko ergonomi 10 yang berarti pertolongan persalinan kala III memiliki tingkat risiko ergonomi yang tinggi untuk menyebabkan adanya keluhan otot. Pada saat subjek penelitian berdiri, maka suplai darah ke otot akan terhambat, sehingga menyebabkan iskemia yang berakibat pada kurangnya asupan oksigen dan meningkatnya $\mathrm{CO}_{2}$ dan zat lain seperti asam laktat, yang menyebabkan keluhan otot pada daerah punggung, leher, bahu dan kaki (otot yang digunakan untuk mempertahankan posisi berdiri).${ }^{30}$ Bidan tidak hanya akan merasakan ketegangan otot tapi juga ketidaknyamanan lainnya. Sikap kerja yang tidak alamiah seperti memutar, membungkuk, menjangkau ini menyebabkan sendi di tulang belakang, pinggul, lutut dan kaki untuk sementara tidak bergerak atau terkunci. ${ }^{8}$ Penelitian Nowotny menyebutkan bahwa pada saat melakukan pertolongan persalinan kala III terdapat kelebihan beban/overload pada daerah tulang belakang bagian servikal dan daerah lumbar. ${ }^{4}$ Hal inilah yang menyebabkan subjek penelitian merasakan ketidaknyamanan pada saat melakukan pertolongan persalinan kala III.

Selama pertolongan kelahiran plasenta (kala III) bidan banyak melakukan aktifitas berulang oleh pergelangan dan telapak tangan untuk memastikan plasenta telah lepas dari dinding rahim. Pergelangan tangan dan telapak tangan kanan menggunakan tenaga yang cukup kuat untuk membantu kelahiran plasenta, tangan kiri dan menahan rahim keatas untuk mencegah rahim ikut keluar bersama plasenta. Kegiatan ini terus dilakukan berulang (repetisi) hingga plasenta bener-benar telah lahir lengkap. Menurut Silverstain dalam Barbe, repetisi terjadi pada saat adanya gerakan yang sama dan berdurasi pendek $(<30$ detik untuk kategori tinggi ataupun $>30$ 
detik untuk kategori ringan) yang dilakukan secara berulang. Hal ini dapat meningkatkan penggunaan otot-otot pada lengan, pergelangan tangan dan telapak tangan. ${ }^{5}$ Setiap pekerja yang memiliki pekerjaan dengan melibatkan gerakan berulang pada lengan, pergelangan tangan-tidak harus bertenaga-dapat berkembang menjadi carpal tunnel syndrome. ${ }^{5,27}$

Pada kelompok perlakuan yang memanfaatkan fitur pengaturan ketinggian, void, dan bagian bawah kursi yang dapat dicopot, memposisikan subjek penelitian dekat dengan posisi ibu bersalin dan tepat didepan jalan lahir pada saat pertolongan persalinan kala III, sehingga postur tubuh cenderung pada posisi netral karena tidak terlalu banyak menjangkau, membungkuk, atau melakukan gerakan dengan posisi kepala yang tidak alamiah. $^{13}$ Sehingga risiko ketidaknyamanan saat pertolongan persalinan kala III akan berkurang.

\section{SIMPULAN}

Hasil penelitian menyimpulkan bahwa terdapat pengaruh penggunaan kursi persalinan $\quad$ BC-MK15 terhadap penurunan ketidaknyamanan bidan dalam pertolongan persalinan kala I, II dan III.

\section{DAFTAR PUSTAKA}

1. Schluter PJ, Turner C, Huntington AD, Bain CJ, McClure RJ. Work/life balance and health: The Nurses and Midwives e-cohort study. Int Nurs Rev. 2011;58(1):2836.

2. Hignett $S$. identification of risk factors. $\mathrm{Br} \quad \mathrm{J}$ Midwifery. 1996;4(11):590-6.

3. Stichler JF, Feiler JL, Chase K. Understanding Risks of Workplace Injury in Labor and Delivery. JOGNN. 2011;41:71-81.

4. Nowotny-Czupryna O, Naworska B, Brzęk A, Nowotny J, Famuła A, Kmita B, et al. Professional experience and ergonomic aspects of midwives' work. Int J Occup Med Environ Health [Internet]. 2012;25(3):265-74. Available from: http://www.ncbi.nlm.nih.gov/pubme d/22791592\%5Cnhttp://ijomeh.eu/P rofessional-experience-andergonomic-aspects-of-midwiveswork,2255,0,2.html

5. Barbe MF, Barr AE. Inflammation and the pathophysiology of workrelated musculoskeletal disorders. 
Brain Behav Immun. 2006;20:4239.

6. Long MH, Bogossian FE, Johnston V. Functional consequences of work-related spinal musculoskeletal symptoms in a cohort of Australian midwives. Women and Birth [Internet]. 2013;26(1):e50-8. Available from: http://dx.doi.org/10.1016/j.wombi.2 012.09 .005

7. Wicaksono B. Faktor yang berhubungan dengan nyeri punggung bawah pada bidan saat menolong proses persalinan. Universitas Airlangga; 2012.

8. Komala R, Modjo R. Faktor-Faktor Yang Berhubungan Terhadap Keluhan Musculoskeletal Disorders ( MSDs ) Pada Bidan Di Pusat Kesehatan Masyarakat Dengan Tempat Bersalin ( Puskesmas DTP ) Kota Bandung Tahun 2013. 2013.

9. rekap studi pendahuluan(1).

10. Straker LM. Body Discomfort: Assessment tools. In: Occupational Ergonomics: Engineering and Administrative Controls. 2005. p. 26-40.

11. Staton N, Hedge A, Brookhuis K, Salas E, Hendrick H, Stolwijk JAJ. Handbook of Human Factors and
Ergonomics Methods. In: handbook of human factors and ergonomics methods. Boca Raton: CRC Press; 2005. p. 76-86.

12. Kee D, Lee I. Relationships between subjective and objective measures in assessing postural stresses. Appl Ergon [Internet]. 2012;43(2):277-82. Available from:

http://dx.doi.org/10.1016/j.apergo.2 011.06 .002

13. Tarwaka. Ergonomi untuk keselamatan, kesehatan kerja dan produktifitas. 1st ed. surakarta: UNIBA Press; 2004.

14. NHS Lothian Midwifery Guidance. nhsggc-midwifery-mh-guidance. 2011. p. 1-7.

15. Wajdi F, Cahyadi D. ANALISIS KELUHAN FISIK BIDAN AKIBAT MENOLONG PARTUS. In: Seminar Nasional Sains dan Teknologi Fakultas Teknik Universitas Muhammadiyah Jakarta. Jakarta; 2016. p. 1-7.

16. Yap B. Ergonomic design of a physiologic birth support system. Massey University New Zealand; 1996.

17. Reenen HHH. Does musculoskeletal discomfort at work 
predict future musculoskeletal.

Ergon J. 2008;51(December 2014):37-41.

18. Kilpatrick S, Garrison E. Chapter 13: Normal Labor and Delivery. In: Obstetrics: Normal and Problem Pregnancies [Internet]. Sixth Edit. Elsevier Inc.; 2012. p. 267-86. Available from: http://dx.doi.org/10.1016/B978-14377-1935-2.00013-2

19. Liao JB, Buhimschi CS, Norwitz ER. Normal labor: Mechanism and duration. Obstet Gynecol Clin North Am. 2005;32(2):145-64.

20. Cunningham.F.G, Leveno.K.J, Bloom.F.L, Spong.C.Y, Dashe.J.S HB. section 7. In: Williams obstetrics. 24th ed. New York: McGraw Hill Education; 2007. p. 408-33.

21. JNPK-KR. Penuntun Belajar Keterampilan Asuhan Persalinan Normal. Jakarta; 2012. p. 1-6.

22. McKeown C. A Guide to Human Factors and Ergonomics [Internet]. Vol. 51, Ergonomics. 2008. 949951 p. Available from: 10.1080/00140130701680379\%5C nhttp://search.ebscohost.com/login. asp $x$ ?direct=true $\& \mathrm{db}=\mathrm{pbh} \& \mathrm{AN}=32$ 069435\&lang=fr\&site=ehost-live
23. Widinugroho BP, Teknik F, Studi $\mathrm{P}$, Industri $\mathrm{T}$. Universitas indonesia evaluasi postur kerja mahasiswa/i tingkat profesi fkg-ui pada tindakan pembersihan karang gigi dengan posisi duduk dalam. Universitas Indonesia; 2011.

24. Rusdiana D. Gambaran kenyamanan posisi duduk ibu menyusui dikelurahan pisangan tahun 2013. Universitas Islam Negeri Syarif Gidayatullah; 2013.

25. Man HU, Zhang L, Interior D, Systems L, Helander MG. Identifying Factors of Comfort and Discomfort in Sitting. 1996;38(3):377-89.

26. OSHA. Ergonomics: The Study of Work. Vol. 2000. 2000.

27. Barr AE, Barbe MF, Billing S, Clark BD, Changes S, Email F. Work-Related Musculoskeletal Disorders: Rev Lit Arts Am. 2004;3970.

28. Long MH, Johnston V, Bogossian F. Work-related upper quadrant musculoskeletal disorders in midwives, nurses and physicians: A systematic review of risk factors and functional consequences. Appl Ergon [Internet]. 2012;43(3):45567. Available from: 
http://dx.doi.org/10.1016/j.apergo.2 011.07 .002

29. Drury CG, Francher M. Evaluation of a forward-sloping. 1985;(March):41-7.

30. Pheasant S. Bodyspace. second edi. Philadelphia: Taylor Francis; 2003.

31. Alnaser MZ, Wughalter EH. Effect of chair design on ratings of discomfort. 2009;34:223-34.

32. Gupta J, Hofmeyr G, Shehmar M. Position in the second stage of labour for women without epidural anaesthesia ( Review ). Cochrane. 2012;(5):1-92.

33. Chuan TK, Hartono M, Kumar N. Anthropometry of the Singaporean and Indonesian populations. Int $\mathbf{J}$ Ind Ergon [Internet]. 2010;40(6):757-66. Available from:

http://dx.doi.org/10.1016/j.ergon.20 10.05.001

34. Habanananda T. NonPharmacological Pain Relief in Labour. 2004;87:194-202.

35. Ebe K, Griffin MJ. Factors affecting static seat cushion comfort. Ergonomics. 2001;44(10):901-21.

36. Kaur N, Miller L, Njndam D, Rubis N, Sennett F. Engineering Design
Report Reconfigurable Obstetrics Delivery Bed. Michigan; 2009.

37. Documents USP, Company $\mathrm{H}$. United States Patent [ 191 Patent Number: Date of Patent; References Cited US . Patent. United States; 1991.

38. Sunandi I, Ginting M, Marpaung.B. Perancangan Ergonomis Tempat Tidur Rumah Sakit. J Ilm Tek Ind. 2013;1(2):95-102.

39. Steering Committee for the Workshop on Work-Related Musculoskeletal Injuries: The Research Base. Work-Related Musculoskeletal Disorders: Report, Workshop Summary, and Workshop Papers. In 1999. p. 240.

40. Hedge A, Ray EJ. Effects of an Electronic Height-Adjustable Worksurface on Computer Worker Musculoskeletal Discomfort and Productivity. Proc Hum Factors Ergon Soc Annu Meet [Internet]. 2004;48(8):1091-5. Available from:

http://www.ergo.human.cornell.edu /Pub/HFlabReports/EHARep0904. pdf\%5Cnhttp://pro.sagepub.com/lo okup/doi/10.1177/15419312040480 0803 
41. Dahlan M. Besar sampel dalam penelitian kedokteran dan kesehatan. edisi 4. Jakarta: epidemiologi indonesia; 2016. 179$181 \mathrm{p}$.

42. Sastroasmoro.S. Dasar dasar metodologi penelitian klinisPemilihan subyek penelitian. In: Dasar dasar metodologi penelitian klinis. edisi keem. Jakarta: Sagung seto; 2012. p. 89101.

43. Cameron JA. Assessing workrelated body-part discomfort: Current strategies and a behaviorally oriented assessment tool 1. Int $\mathbf{J}$ Ind Ergon. 1996;8141(95).

44. Marley RJ, Kumar N. An improved musculoskeletal discomfort assessment tool. Int $\mathbf{J}$ Ind Ergon. 1996;17(1):21-7.

45. Messing K, Vézina N, Major M-È, Ouellet S, Tissot F, Couture V, et al. Body maps : an indicator of physical pain for worker-oriented ergonomic interventions. Policy Pract Heal Saf. 2008;6(2):31-49.

46. Dahlan M. Statistik untuk kedokteran dan kesehatan. edisi 6 . epidemiologi indonesia; 2016.

47. Webb P. Why? Linking exposure and disease. In: Essential Epidemiology. fifth ed. Cambridge: Cambridge university press; 2007. p. 89-105.

48. Gradjean $\mathrm{K}$ and. Fitting the task to the human: A textbook of Occupational ergonomics. London and NewYork: Taylor \& Francis; 2005 